\title{
Biogenic synthesis of gold nanoparticles using Argemone mexicana L. and their cytotoxic and genotoxic effects on human colon cancer cell line (HCT-15)
}

\author{
Kailas D. Datkhile* D, Satish R. Patil, Pratik P. Durgawale, Madhavi N. Patil, Dilip D. Hinge, Nilam J. Jagdale,
} Vinit N. Deshmukh and Ashwini L. More

\begin{abstract}
Background: Nanomedicine has evolved as precision medicine in novel therapeutic approach of cancer management. The present study investigated the efficacy of biogenic gold nanoparticles synthesized using Argemone mexicana L. aqueous extract (AM-AuNPs) against the human colon cancer cell line, HCT-15.

Results: Biosynthesis of AM-AuNPs was determined by ultraviolet-visible spectroscopy and further characterized by transmission electron microscopy, X-ray diffraction, and Fourier transition infrared spectroscopy analysis. The cytotoxic activity of AM-AuNPs was assessed by the 3-(4, 5-dimethylthiazol-2-yl)-2, 5-diphenyltetrazolium bromide assay, whereas genotoxicity was evaluated by the DNA fragmentation assay. The expression of apoptosis regulatory genes such as p53 and caspase-3 was explored through semi-quantitative reverse transcriptase polymerase chain reaction (RT-PCR) and western blotting to evidence apoptotic cell death in HCT-15 cells. Biogenic AM-AuNPs inhibited cell proliferation in HCT-15 cell line with a half maximal inhibitory concentration $\left(I_{50}\right)$ of $20.53 \mu \mathrm{g} / \mathrm{mL}$ at $24 \mathrm{~h}$ and $12.03 \mu \mathrm{g} / \mathrm{mL}$ at $48 \mathrm{~h}$ of exposure. The altered cell morphology and increased apoptosis due to AM-AuNPs were also evidenced through nuclear DNA fragmentation and upregulated expression of p53 and caspase-3 in HCT-15 cells.

Conclusion: The AM-AuNPs may exert antiproliferative and genotoxic effects on HCT-15 cells by cell growth suppression and induction of apoptosis mediated by activation of p53 and caspase-3 genes.
\end{abstract}

Keywords: Apoptosis, Argemone mexicana, Cell proliferation, Cytotoxicity, Gold nanoparticles

\section{Background}

Biogenic nanoparticles have attracted interest in recent years due to their potential in industrial, biomedical, and pharmaceutical applications. Metal nanoparticles are of particular significance in several biomedical applications such as targeted drug delivery, bio-imaging, and photo dynamic therapy $[1,2]$. As per the world cancer report, cancer is a leading cause of mortality in both developing and developed countries, with 18.1 million new cases

\footnotetext{
* Correspondence: hodgeneticslab@kimsuniversity.in

Department of Molecular Biology and Genetics, Krishna Institute of Medical

Sciences "Deemed to be University", Taluka-Karad, Dist-Satara, Malkapur,

Maharashtra Pin-415 539, India
}

\section{SpringerOpen}

(c) The Author(s). 2021 Open Access This article is licensed under a Creative Commons Attribution 4.0 International License, which permits use, sharing, adaptation, distribution and reproduction in any medium or format, as long as you give appropriate credit to the original author(s) and the source, provide a link to the Creative Commons licence, and indicate if changes were made. The images or other third party material in this article are included in the article's Creative Commons licence, unless indicated otherwise in a credit line to the material. If material is not included in the article's Creative Commons licence and your intended use is not permitted by statutory regulation or exceeds the permitted use, you will need to obtain permission directly from the copyright holder. To view a copy of this licence, visit http://creativecommons.org/licenses/by/4.0/.

and 9.6 million cancer deaths occurring worldwide in 2018 [3]. The current chemotherapeutic approach toward cancer management is insubstantial because of the associated side effects and multidrug resistance. Therefore, researchers worldwide are attempting alternative strategies such as various nano-formulations as promising nano-weapons for efficacious cancer management [4-7]. Metal nanoparticles are considered in biomedical applications because of their biodistribution, augmented efficacy, and reduced toxicity $[8,9]$. Biosynthesis of metal nanoparticles is emerging in nanotechnology for the preparation of various homogenous nanoparticles because of its non-toxicity, biocompatibility, and 
ecofriendliness. The secondary metabolites of plant extracts used in the green synthesis of nanoparticles may enhance their biological potential. The synthesis and biological properties of silver and other metal nanoparticles are widely studied. Biogenic silver nanoparticles are significantly illustrated for their biological efficacies including antimicrobial and anticancer potential, but the gold nanoparticles remained poorly characterized for their biomedical applications. Gold nanoparticles (AuNPs) are being widely used in biomedicine as they can specifically target diseased areas and interact with cellular biomolecules [10-12]. Some studies reported strong anticancer potential of AuNPs synthesized using Dunaliella salina and Dragon fruit plants against breast cancer cell lines [13, 14]. Other studies revealed dose-dependent cytotoxicity activity of gold nanoparticles synthesized using plant extracts against lung and bladder cancer cell lines [15-17]. Several in vitro studies have elaborated the mechanism of the anticancer activity of AuNPs where the nanoparticles enter the cells through the permeability and retention effect or nonspecific receptor-mediated endocytosis. Mechanistically, AuNP-treated cancer cell lines displayed generation of reactive oxygen species leading to the membrane damage via oxidation of proteins and lipids, enhanced mitochondrial activity, and ultimately leading to the death of cancer cells $[18,19]$. It was also reported that the AuNPs target the cellular organelleles and induce nuclear DNA damage [20]. Although numerous scientists have explored the anticancer potential of biosynthesized nanoparticles, the effect of AuNPs on colon cancer cells remains unclear. Additionally, the intracellular and molecular level interaction of biogenic AuNPs and the precise mechanism involved in the regulation of cytotoxicity and genotoxicity in response to AuNPs remained poorly understood.

Argemone mexicana, a Mexican poppy plant, has diverse biological properties such as free radical scavenging, and antimicrobial and antiparasitic activities. Recently, the antiproliferative effects of the A. mexicana plant extract have been reported on various cancer cell lines [21, 22]. In earlier studies, we demonstrated that biogenic silver nanoparticles synthesized using $A$. mexicana can induce cell death through inhibition of cell proliferation and the p53-mediated apoptotic pathway in human cancer cells [23]. However, AuNPs of this plant against colon cancer has yet to be studied. Therefore, the current study explored the possible mechanism involved in the inhibition of cell proliferation and involvement of p53 and caspase- 3 in the regulation of the apoptotic pathway in HCT-15 cell lines in response to AuNPs biosynthesized using the aqueous extract of $A$. mexicana plant (AM-AuNPs). AM-AuNPs were characterized by UV-visible spectroscopy followed by characterization of size and shape of nanoparticles suing transmission electron microscopy (TEM), X-ray diffraction (XRD), and Fourier transition infrared spectroscopy (FTIR). AM-AuNPs were tested for their cytotoxic activity using the 3-(4, 5dimethylthiazol-2yl)-2, 5-diphenyltetrazolium bromide (MTT) assay, whereas the genotoxic effects were determined using the DNA fragmentation assay. The apoptotic features were further explored through the profiling of expression of apoptosis regulatory genes at the mRNA and protein level by using semi-quantitative reverse transcriptase polymerase chain reaction (RT-PCR) and western blotting, respectively.

\section{Methods}

\section{Preparation of aqueous plant extract for nanoparticle synthesis}

Whole A. mexicana plants were collected from the arid region of the Western Ghats of south-western Maharashtra, India, and authenticated at the Department of Botany, University of Pune, Maharashtra, India. The plant parts were thoroughly washed with distilled water for removing of adhered dust particles, dried, and then ground into fine powder using mortar and pestle. The aqueous extract was prepared by mixing $100 \mathrm{~g}$ of leaf powder in $1000 \mathrm{~mL}$ of double distilled water and boiled at $80^{\circ} \mathrm{C}$ for $30 \mathrm{~min}$ in a flask. After cooling, the aqueous extract was filtered through Whatman filter paper. Thereafter, it was passed through a $0.22-\mu \mathrm{m}$ filter, and the filtrate was used for AuNP biosynthesis.

\section{Biosynthesis and purification of AuNPs}

The AuNPs were synthesized by adding $100 \mathrm{~mL}$ of aqueous plant extract to $900 \mathrm{~mL}$ of $1 \mathrm{mM}$ gold (III) chloride trihydrate $\left(\mathrm{HAuCl}_{4} \cdot 3 \mathrm{H}_{2} \mathrm{O}\right)$ solution. The preparation was then incubated at $80^{\circ} \mathrm{C}$ in the dark and monitored for change in color, indicating synthesis of nanoparticles. The AM-AuNPs were centrifuged at 15,000 rpm for 10 min and washed several times with sterile deionized water to remove unwanted traces of contaminants, followed by redispersion of the pellet in sterile distilled water for further characterizations.

\section{Characterization of biogenic AuNPs}

The reduction of gold chloride solution using the aqueous plant extract was monitored for $30,60,120$, and $180 \mathrm{~min}$, and the appearance of purple color indicated the formation of AuNPs. The primary characterization of the biosynthesized AM-AuNPs was performed using UV-visible spectroscopy by measuring the UV-visible spectrum of the reaction mixture at $200-800 \mathrm{~nm}$ wavelength by sampling the aliquots withdrawn from the reaction mixture at different time intervals. The AMAuNPs were further characterized through TEM, XRD, 
and FTIR analyses at the Sophisticated Analytical Instrument Facility, Sophisticated Test and Instrumentation Center, Cochin University, Kerala.

In vitro evaluation of cytotoxicity properties of AM-AuNPs The HCT-15 cell line obtained from the National Centre for Cell Sciences, Pune, India, was grown in a T-25 flask containing RPMI-1640 medium supplemented with $10 \%$ fetal bovine serum (FBS) and $100 \mathrm{U} / \mathrm{mL} / 100 \mu \mathrm{g} / \mathrm{mL}$ penicillin-streptomycin. The cells were maintained at $5 \%$ $\mathrm{CO}_{2}, 95 \%$ humidity, and $37^{\circ} \mathrm{C}$ temperature. The in vitro effect of AM-AuNPs on the cell proliferation of HCT-15 cells was determined by the MTT colorimetric assay. Approximately $1 \times 10^{4}$ cells were seeded in each well of 96-well plate in $200 \mu \mathrm{L}$ of medium and incubated at $37{ }^{\circ} \mathrm{C}, 5 \% \mathrm{CO}_{2}$. After $24 \mathrm{~h}$ of incubation, $\sim 70 \%$ confluent cells were exposed to AM-AuNPs at 5, 10, 20, 25, and $50 \mu \mathrm{g} / \mathrm{mL}$ in the culture medium without FBS and incubated for further $48 \mathrm{~h}$. After completion of $24 \mathrm{~h}$ and $48 \mathrm{~h}$ treatment, the medium was removed, and the cells were washed with Hanks' Balanced Salt Solution (HBSS), and cell viability was measured by MTT assay. A total of $10 \mu \mathrm{L}$ of MTT $(5 \mathrm{mg} / \mathrm{mL})$ was added to each well, and the cells were further incubated for another $4 \mathrm{~h}$ at $37^{\circ} \mathrm{C}$ and $5 \% \mathrm{CO}_{2}$ atmosphere. After $4 \mathrm{~h}$ of incubation, the MTT-containing medium was discarded, and cells were washed with HBSS; thereafter, $200 \mu \mathrm{L}$ of dimethyl sulfoxide was added to each well to dissolve the formazan crystals. The absorbance of the developed purple color was measured at 560-nm wavelength using the UV-Vis 1800 spectrophotometer (Shimadzu) to determine the percentage inhibition of growth of both treated and untreated cells. The effect of AM-AuNPs on cell proliferation was expressed as percentage (\%) growth inhibition, by using the following formula: percentage (\%) inhibition $=100-($ A560 $\mathrm{nm}$ of treated cells/A560 nm of control cells) $\times 100 \%$. The half-maximal inhibitory concentration $\left(\mathrm{IC}_{50}\right)$ values with a $95 \%$ confidence interval were calculated using the SPSS 11 for Windows software.

\section{Cell morphology}

A total of $1 \times 10^{6} \mathrm{HCT}-15$ cells/well were cultured in 6well culture plates and incubated at $37{ }^{\circ} \mathrm{C}$ in $5 \% \mathrm{CO}_{2}$ for $24 \mathrm{~h}$. Later, the cells were treated with different concentrations $(5,10,20,25$, and $50 \mu \mathrm{g} / \mathrm{mL})$ of AM-AuNPs in culture medium without FBS and further incubated up to $48 \mathrm{~h}$. The cell morphology was then observed under the Primovert phase-contrast microscope at $\times 20$ magnification (Carl Zeiss).

\section{Evaluation of genotoxic activity of AM-AuNPs DNA fragmentation assay}

For analyzing the genotoxic effects of AM-AuNPs, $1 \times$ $10^{6}$ cells in 6 -well plates were treated with $0-50 \mu \mathrm{g} / \mathrm{mL}$ concentrations of AM-AuNPs along with untreated controls and incubated at $37{ }^{\circ} \mathrm{C}$ in $5 \% \mathrm{CO}_{2}$, for $48 \mathrm{~h}$. The cells were harvested by trypsinization with $0.25 \%$ trypsin-EDTA for $10 \mathrm{~min}$, and suspended cells were washed once with HBSS by centrifugation. Thereafter, the cells were lysed in $0.3 \mathrm{~mL}$ of cell lysis buffer containing $10 \mathrm{mM}$ Tris- $\mathrm{HCl}, \mathrm{pH} 7.5,1 \mathrm{mM}$ ethylenediaminetetraacetic acid (EDTA), $0.2 \%$ triton $\mathrm{X}-100,0.5 \%$ sodium dodecyl sulfate (SDS). The cell lysate was incubated with $0.5 \mathrm{mg} / \mathrm{mL}$ RNase A at $37^{\circ} \mathrm{C}$ for $1 \mathrm{~h}$, thereafter, $0.2 \mathrm{mg} /$ $\mathrm{mL}$ of proteinase $\mathrm{K}$ at $55^{\circ} \mathrm{C}$ for $1 \mathrm{~h}$. DNA in the aqueous phase was precipitated by adding $1 / 10$ th volume of $5 \mathrm{M}$ sodium chloride and equal volume of isopropanol at $20^{\circ} \mathrm{C}$. After $1 \mathrm{~h}$ incubation, the suspension was centrifuged at $12000 \times g$ for $30 \mathrm{~min}$ at $4{ }^{\circ} \mathrm{C}$ followed by DNA pellet wash by $70 \%$ ice cold ethanol and air-dried DNA pellet for $10 \mathrm{~min}$ at room temperature. The DNA was resuspended in appropriate volume of $\mathrm{T}_{10} \mathrm{E}_{1}$ buffer $(\mathrm{pH}$ 8.0). The DNA was examined on a $1.5 \%(\mathrm{w} / \mathrm{v})$ low EEO agarose (GeNei) gel containing $1 \mu \mathrm{g} / \mathrm{mL}$ ethidium bromide and subjected to electrophoresis at $80 \mathrm{~V}$ for $1-2 \mathrm{~h}$ in tris-acetate-EDTA (TAE) buffer along with DNA molecular weight marker. The DNA fragments were visualized by exposing the gels to the UV transilluminator followed by photography in the gel documentation system (BioRad Laboratories, USA).

\section{Caspase-3 assay}

To examine the apoptosis of HCT-15 cell line, $1 \times 10^{6}$ cells were seeded in 6-well plates and incubated for $24 \mathrm{~h}$ at $37{ }^{\circ} \mathrm{C}$ in $5 \% \mathrm{CO}_{2}$. Thereafter, the control and AMAuNP $(12.03 \mu \mathrm{g} / \mathrm{mL})$-treated cells were harvested by trypsinization at different time points $(0,24$, and $48 \mathrm{~h})$ and washed with ice-cold phosphate-buffered saline. Caspase3 activity was measured in the cancer cells using a caspase-3 assay kit (Sigma, USA) according to the manufacturer's instructions. HCT-15 cells were lysed with $100 \mu \mathrm{L}$ of lysis buffer (50 mM HEPES (pH 7.4), $5 \mathrm{mM}$ CHAPS $5 \mathrm{mM}$ dithiothreitol (DTT) for $30 \mathrm{~min}$ at $4{ }^{\circ} \mathrm{C}$ ). Protein extracts were collected after centrifugation at 12 , $000 \times g$ for $20 \mathrm{~min}$. An equal volume $(10 \mu \mathrm{L})$ of protein extracts was mixed with the assay buffer (20 mM HEPES (pH 7.4), 0.1\% CHAPS, $10 \mathrm{mM}$ DTT, $1 \mathrm{mM}$ EDTA), and incubated with the caspase-3 substrate (acetyl-Asp-GluVal-Asp p-nitroanilide (Ac-DEVD-pNA)) and caspase-3 inhibitor (Ac-DEVD-CHO) for $4 \mathrm{~h}$. Then, the absorbance was measured at $405 \mathrm{~nm}$ using a double-beam UV-visible spectrophotometer. The assay was also performed with noninduced cells and in the presence of the caspase- 3 inhibitor for a comparative analysis.

\section{Annexin V-FITC assay}

A total of $1 \times 10^{6} \mathrm{HCT}-15$ cell lines were seeded in a 6well plate and incubated for $24 \mathrm{~h}$ at $37^{\circ} \mathrm{C}$ in $5 \% \mathrm{CO}_{2}$, 
followed by exposure to 5,10 , and $25 \mu \mathrm{g} / \mathrm{mL}$ of AMAuNPs with incubation periods of 24 and $48 \mathrm{~h}$. After treatment completion, the cells were harvested by trypsinization and washed with $1 \times$ HBSS. Thereafter, apoptosis was detected by using the Annexin V-FITC assay kit (Sigma). The cells were resuspended in $1 x$ binding buffer and stained with $5 \mu \mathrm{L}$ of the Annexin V-FITC conjugate and $10 \mu \mathrm{L}$ of $100 \times$ propidium iodide for $10 \mathrm{~min}$ at room temperature in the dark. The cell samples were analyzed using the BD-FACSCelesta flow cytometer (BD-Biosciences) at IISER, Pune.

\section{Semi-quantitative RT-PCR analysis for apoptotic gene expression}

In the present study, total RNA was extracted from the control and AM-AuNP-treated HCT-15 cells at an $\mathrm{IC}_{50}$ of $12.03 \mu \mathrm{g} / \mathrm{mL}$ by the Trizol reagent after 24 and $48 \mathrm{~h}$ of exposure. RNA quantitation and purity were examined by measuring absorbance of the RNA sample at 260 and $280 \mathrm{~nm}$ with the following equation: 1OD at $260 \mathrm{~nm}=40 \mu \mathrm{g}$. Thereafter, equal amounts of RNA $(5 \mu \mathrm{g})$ were used for cDNA synthesis in a $20 \mu \mathrm{L}$ reaction mixture containing $1 \mu \mathrm{L}$ verso enzyme mix comprising verso reverse transcriptase, $4 \mu \mathrm{L} 5 \times$ cDNA synthesis buffer (Thermo Scientific), $5 \mu \mathrm{g}$ of total RNA, $2 \mu \mathrm{L}$ of dNTPs (0.5 mM each) (Thermo Scientific), $1 \mu \mathrm{L}$ of RT enhancer, $1 \mu \mathrm{L}$ of mixture of random hexamers, and anchored oligo-dT (3:1) (Thermo Scientific). cDNA synthesis was performed by reverse transcription cycling program at $42{ }^{\circ} \mathrm{C}$ for $30 \mathrm{~min}$, followed by inactivation at $95^{\circ} \mathrm{C}$ for $2 \mathrm{~min}$ to remove the contaminating DNA. Thereafter, $2 \mu \mathrm{L}$ of each cDNA was amplified in a $20 \mu \mathrm{L}$ PCR reaction mixture containing one unit Taq DNA polymerase, $2 \mu \mathrm{L} 10 \times$ PCR buffer, $0.5 \mu \mathrm{L}$ of dNTP (200 $\mu \mathrm{M}$ each), and 10 picomole of forward primer $5^{\prime}$ actaagcgagcactgcccaa- $3^{\prime}$ and reverse primer $5^{\prime}$-atggcgggaggtagactgac- $\left.3^{\prime}\right)$ of $\mathrm{p} 53$, and forward primer $5^{\prime}$ gtggcattgagacagacagtgg- $3^{\prime}$ reverse primer $5^{\prime}$-gccaagaataataaccaggtgc- $3^{\prime}$ of caspase-3. Cycling conditions comprised an initial denaturation of $5 \mathrm{~min}$ at $94^{\circ} \mathrm{C}$ followed by 30 cycles of amplification at $94{ }^{\circ} \mathrm{C}$ for $30 \mathrm{~s}, 50{ }^{\circ} \mathrm{C}$ for $30 \mathrm{~s}$, and $72{ }^{\circ} \mathrm{C}$ for $30 \mathrm{~s}$, and the final elongation step at $72{ }^{\circ} \mathrm{C}$ for $10 \mathrm{~min}$. To control the PCR reaction components and RNA integrity, $2 \mu \mathrm{L}$ of each cDNA sample was amplified separately for glyceraldehyde 3-phosphate dehydrogenase (GAPDH) specific primers. The electrophoretic separation of amplification products was performed with $2.5 \%$ agarose gel in tris-borate-EDTA

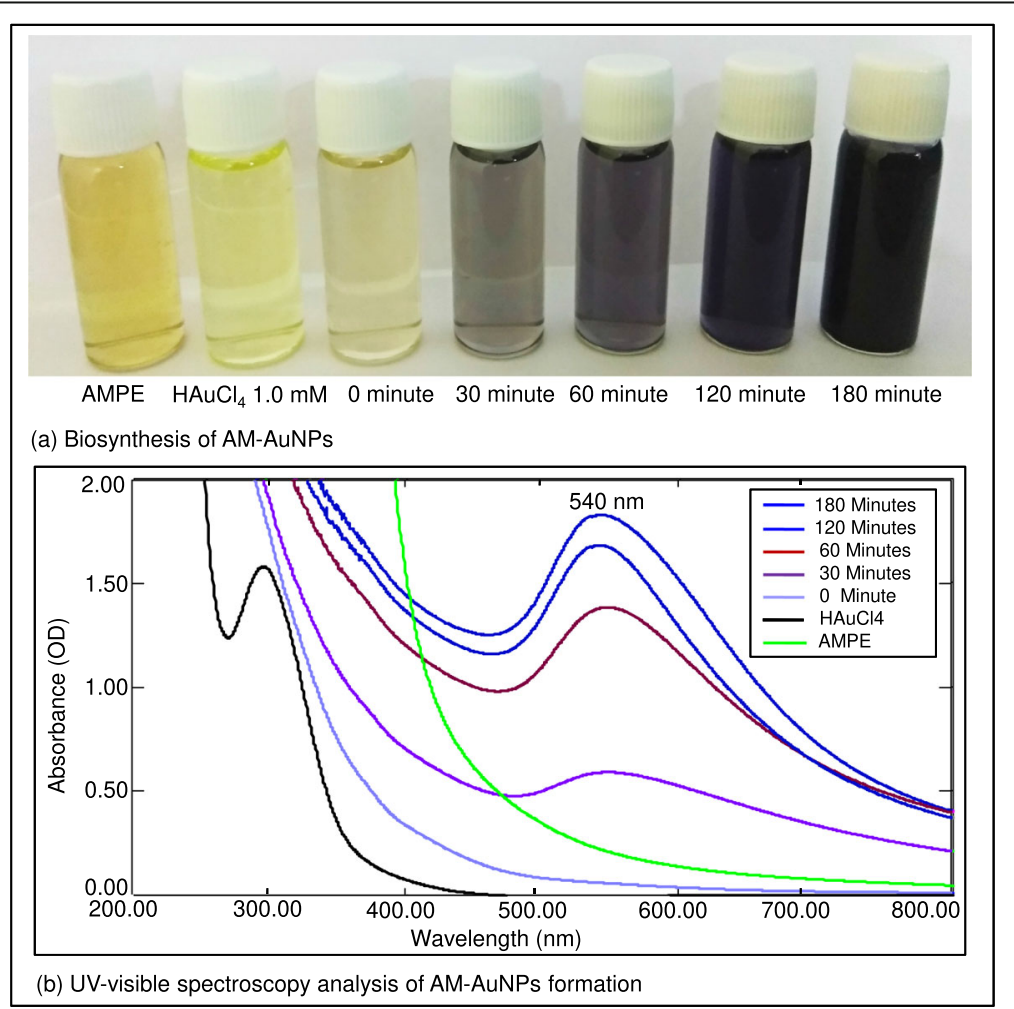

Fig. 1 a Biosynthesis of gold nanoparticles indicating transformation of color of reaction mixture containing A. mexicana plant extract and 1 mM $\mathrm{HAuCl} 4 \cdot 3 \mathrm{H} 2 \mathrm{O}$ solution at various time periods (0-180 min). b Time-dependent UV-visible spectrometry analysis of AM-AuNPs formation showing spectra of A. mexicana plant extract, $\mathrm{HAuCl} 43 \mathrm{H} 2 \mathrm{O}$, and AM-AuNPs. The absorption spectrum of biosynthesized AuNPs exhibited a strong peak at $540 \mathrm{~nm}$ 
buffer. The images of ethidium bromide-stained PCR products were captured using Molecular Imager Chemi $\mathrm{Doc}^{\mathrm{TM}} \mathrm{XRS}^{+}$, and the relative density of amplicons was determined using the image analysis software Image $\mathrm{Lab}^{\mathrm{TM}} 3.0$ (BioRad Laboratories, USA)

\section{Western blotting analysis}

Western blotting was conducted to detect the expression of apoptotic proteins such as p53 and caspase-3 in HCT-15 cells. A total of $1 \times 10^{6}$ cells 6 -well plates were treated with $12.03 \mu \mathrm{g} / \mathrm{mL}$ of AM-AuNPs for $48 \mathrm{~h}$. The cells were harvested with centrifugation at $12,000 \mathrm{rpm}$ for $10 \mathrm{~min}$ at $24 \mathrm{~h}$ intervals. The cell lysate was prepared in a homogenization buffer $(50 \mathrm{mM}$ Tris, $5 \mathrm{mM}$ EDTA, $0.1 \%$ Triton-X100, $1 \mathrm{mM}$ PMSF, $0.5 \mathrm{mM}$ DTT, protease inhibitor cocktail). The separation of $50 \mu \mathrm{g} / \mathrm{lane}$ of proteins was performed using 10\% SDS-PAGE. They were then transferred onto a nitrocellulose membrane. After blocking in tris-buffered saline, $0.1 \%$ Tween-20 solution containing $5 \%(\mathrm{w} / \mathrm{v})$ casein for $1 \mathrm{~h}$, followed by $1 \mathrm{~h}$ incubation with primary antibodies, mouse anti-p53 and rabbit anti-caspase-3, and anti-GAPDH. Thereafter, the membranes were incubated with secondary antibodies (horseradish peroxidase-conjugated rabbit anti-mouse IgG and goat anti-rabbit IgG) for $1 \mathrm{~h}$. Immunoreactive bands were detected using an enhanced chemiluminescence WesternBright ${ }^{\mathrm{TM}}$ ECL detection system (Advansta). The western blot images were captured using Molecular Imager Chemi Doc ${ }^{\text {TM }}$ XRS $^{+}$(BioRad Laboratories), and the relative intensity of luminescent bands was determined using the Image $\mathrm{Lab}^{\mathrm{TM}} 3.0$ software. The expression of each protein was compared with that of GAPDH to account for potential variations in protein estimation and sample loading.

\section{Statistical analysis}

All the experiments were repeated three times independently $(N=3)$, and means of standard deviation (SD) for each group were calculated. The percentage inhibition of cell growth was reported as mean \pm SD of three independent experiments. Student's $t$ test was performed to examine the significant differences between means of expression of p53 and caspase-3 from AM-AuNP treated

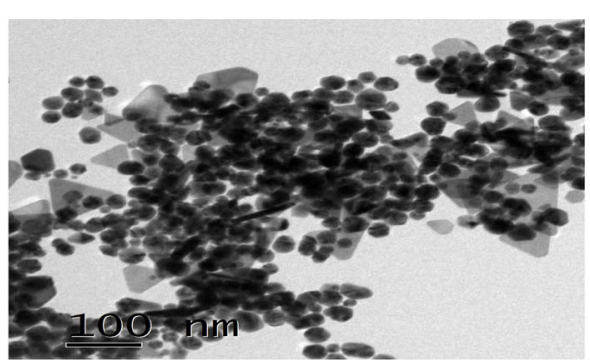

(a)TEM image Scale bar represents $100 \mathrm{~nm}$

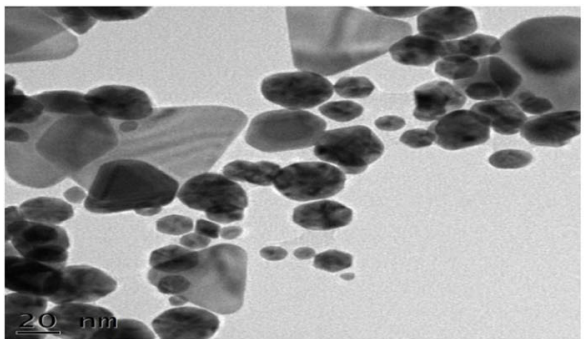

(c) High resolution of nanoparticles at $20 \mathrm{~nm}$



(e) Single Nanocrystal



(b) TEM image Scale bar represents $50 \mathrm{~nm}$



(d) High resolution of nanoparticles at $10 \mathrm{~nm}$

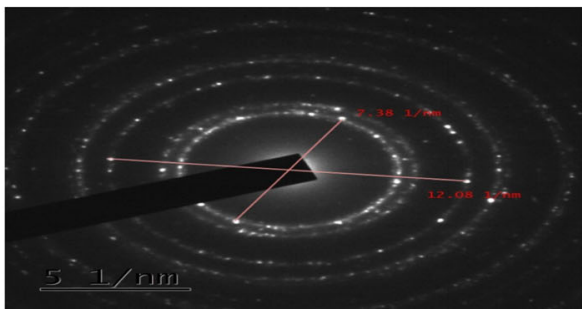

(f) SAED Pattern

TEM Analysis of AM-AuNPs

Fig. 2 TEM analysis of AM-AuNPs (a). Image of AM-AuNPs where scale bar represents $100 \mathrm{~nm}$ (b). Scale bar represents $50 \mathrm{~nm}$ (c). High-resolution of nanoparticles at $20 \mathrm{~nm}(\mathbf{d})$ and $10 \mathrm{~nm}(\mathbf{e})$. Single nanocrystal $(\mathbf{f})$ SAED pattern 
and control samples both at the mRNA and protein level.

\section{Results}

Biosynthesis and characterization of AM-AuNPs

Reduction of gold chloride solution by the A. mexicana aqueous extract determined with the UV-visible absorption spectra at $200-800 \mathrm{~nm}$ revealed the formation of AuNPs. The change in the yellow color of the gold chloride solution to dark purple after $3 \mathrm{~h}$ of incubation with the $A$. mexicana leaf extract indicated the formation of gold nanoparticles, which may be triggered by phytochemicals present in the plant (Fig. 1a). The timedependent UV-visible spectra of biosynthesized AMAuNP solution gave surface plasmon resonance at 540 $\mathrm{nm}$ indicating nanoparticle synthesis (Fig. 1b). These results demonstrated that nanoparticle biosynthesis was initiated after $30 \mathrm{~min}$ of incubation, and the intensity of peak progressively increased and completed after $3 \mathrm{~h}$ of incubation. The TEM results for the characterization of the AM-AuNP, demonstrated mostly hexagonal shape and 20-40-nm-sized AuNPs (Fig. 2a-f). A structural analysis of biosynthesized AuNPs was performed through XRD, and the peaks at 111, 200, 220, and 311 lattice planes clearly confirmed the crystalline structure of AM-AuNPs. The XRD pattern obtained for AM-
AuNPs is illustrated in Fig. 3a. The FTIR spectrum of the biosynthesized AuNPs exhibited peaks at $3449(\mathrm{O}-\mathrm{H}$ bond of alcohol/phenol), 2079 (C triple bonds of alkynes), 1637 ( $\mathrm{C}=\mathrm{C}$ of alkynes), and $578(\mathrm{C}-\mathrm{N}$ bond of amines). The FTIR peaks obtained for AM-AuNPs are illustrated in Fig. 3b.

\section{In vitro cytotoxicity and genotoxicity properties of AM- AuNPs}

The cytotoxicity activity of biosynthesized AM-AuNPs was explored against HCT-15 cells exposed to $0-50 \mu \mathrm{g} /$ $\mathrm{mL}$ concentrations after $24 \mathrm{~h}$ intervals up to $48 \mathrm{~h}$ of exposure (Fig. 4a and b). The morphology of HCT-15 cells was altered and exhibited a shrunken appearance because of loss of membrane integrity and cytoplasmic condensation (Fig. 4c) when treated with a higher concentration $(20-50 \mu \mathrm{g} / \mathrm{mL})$ of AM-AuNPs. At $50 \mu \mathrm{g} / \mathrm{mL}$ of AM-AuNPs, maximum growth inhibition (90.10 \pm $0.96 \%$ ) of HCT-15 cells was observed after $24 \mathrm{~h}$ of exposure (Fig. 4a) and (96.17 $\pm 1.15 \%)$ after $48 \mathrm{~h}$ of exposure (Fig. $4 \mathrm{~b}$ ). The $\mathrm{IC}_{50}$ of AM-AuNPs required to inhibit the growth of HCT-15 cells after $24 \mathrm{~h}$ of exposure was $20.53 \mu \mathrm{g} / \mathrm{mL}$ whereas the requirement for cells after $48 \mathrm{~h}$ of exposure was $12.03 \mu \mathrm{g} / \mathrm{mL}$. When studying the genotoxic effects of biogenic AuNPs, nuclear fragmentation exhibited clear fragmented DNA from cells exposed to


Fig. 3 Characterization of AM-AuNPs (a) XRD pattern of biogenic gold nanoparticles synthesized using A. mexicana plant extract. b FTIR spectrum gold nanoparticles synthesized using aqueous extract of $A$. mexicana plant 




(A) \% inhibition of HCT-15 cells after $24 \mathrm{~h}$ exposure to AM-AuNPs

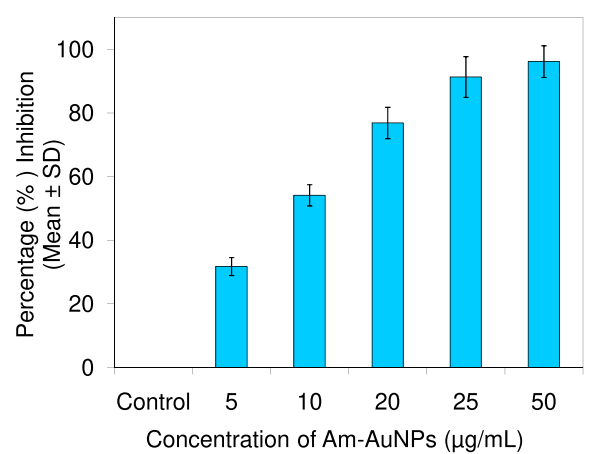

(B) \% inhibition of HCT-15 cells after $48 \mathrm{~h}$ exposure to AM-AuNPs

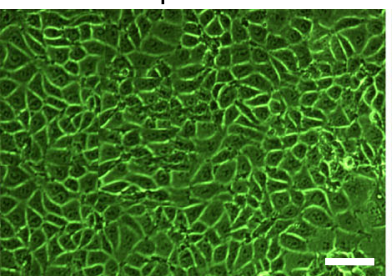

(a) Control

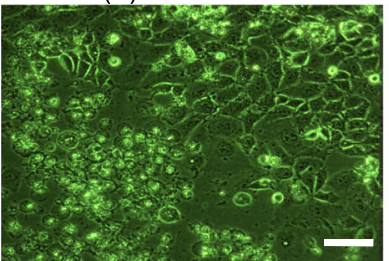

(d) $20 \mu \mathrm{g} / \mathrm{mL}$



(b) $5 \mu \mathrm{g} / \mathrm{mL}$

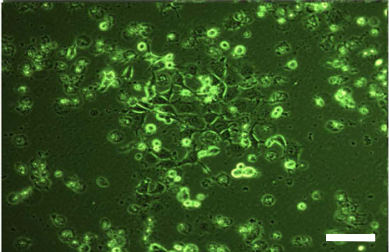

(e) $25 \mu \mathrm{g} / \mathrm{mL}$

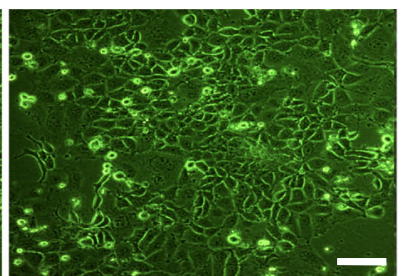

(c) $10 \mu \mathrm{g} / \mathrm{mL}$

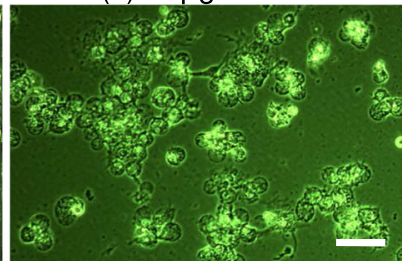

(f) $50 \mu \mathrm{g} / \mathrm{mL}$

(C) Morphology of HCT-15 cells after $24 \mathrm{~h}$ exposure to AM-AuNPs

Fig. 4 Representative histogram showing percentage growth inhibition of HCT-15 cells after (A) $24 \mathrm{~h}$ and (B) $48 \mathrm{~h}$ of exposure to biogenic AMAuNPs at 5, 10, 20, 25, and $50 \mathrm{\mu g} / \mathrm{mL}$ concentrations. The results represent the means of three independent experiments. Error bars represent the standard deviation of means. (C) Morphology of HCT-15 cells after $24 \mathrm{~h}$ exposure of AM-AuNPs with different concentrations (a) control; (b) 5 Hg/ $\mathrm{mL}$; (c) $10 \mu \mathrm{g} / \mathrm{mL}$; (d) $20 \mu \mathrm{g} / \mathrm{mL}$; (e) $25 \mu \mathrm{g} / \mathrm{mL}$; and (f) $50 \mu \mathrm{g} / \mathrm{mL}$. All images are captured at $\times 20$ magnification with phase contrast microscope. Scale bars represent $100 \mu \mathrm{m}$

$5-50 \mu \mathrm{g} / \mathrm{mL}$ of AM-AuNPs, whereas the untreated cells did not exhibit any prominent DNA laddering on agarose gels (Fig. 5a and b). DNA fragmentation revealed extensive double-strand breaks in the DNA of HCT-15 cells in response to higher dosages of AM-AuNPs (20$50 \mu \mathrm{g} / \mathrm{mL}$ ). Additionally, induction of apoptosis in HCT15 cells exposed to AM-AuNPs was investigated by the caspase- 3 assay. In the cells treated with $12.03 \mu \mathrm{g} / \mathrm{mL}$ of AM-AuNPs for $48 \mathrm{~h}$, caspase-3 activity significantly increased after $24 \mathrm{~h}$ and continued till $48 \mathrm{~h}$ of exposure compared with the untreated control cells (Fig. 6a). Finally the Annexin- $\mathrm{V}$ apoptosis assay was performed to understand the mechanism of death of HCT-15 cells in response to biogenic AM-AuNP exposure. When the cells were treated with increased AM-AuNP concentrations, the AM-AuNPs were more effective with increasing concentration in a time-dependent manner. As the time of incubation at higher concentrations increased from 24 to $48 \mathrm{~h}$, the number of viable cells decreased and the number of cells exhibiting early apoptosis, and thereafter late apoptosis, increased (Fig. $6 \mathrm{~b})$. The expression of p53 and caspase- 3 genes at the mRNA (Fig. 7a and b) and protein level (Fig. 7c and d) from HCT-15 cells exposed to AM-AuNPs was assessed to study the consequences of biogenic AuNPs on apoptosis. The expression of both p53 and caspase- 3 genes/ protein was observed to be triggered noticeably in a time-dependent manner.

\section{Discussion}

The present study attempted for the first time to understand the possible mechanism underlying the 


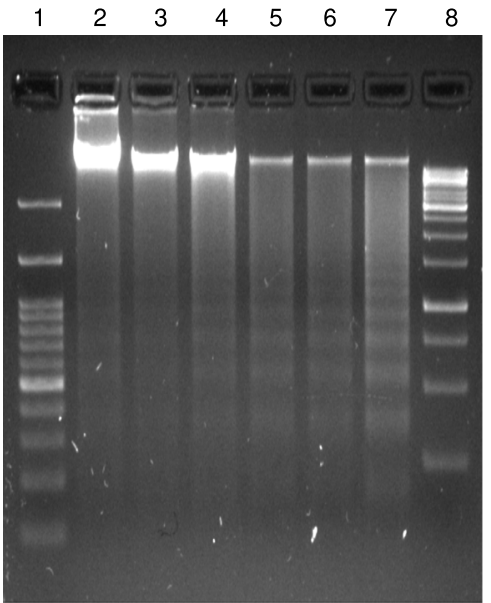

(a) $24 \mathrm{~h}$

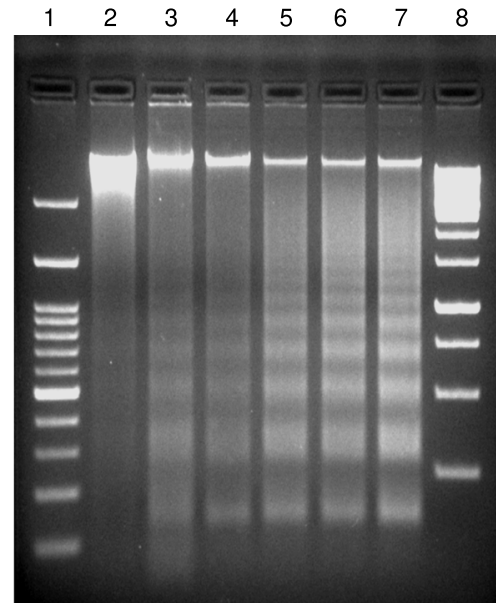

(b) $48 \mathrm{~h}$

Fig. 5 Representative agarose gel images showing DNA fragmentation pattern of HCT-15 cells exposed to different concentrations of AM-AuNPs after different time periods of exposure $\mathbf{a} 24 \mathrm{~h}$ and $\mathbf{b} 48 \mathrm{~h}$. In each representative gel, lane 1 is $100 \mathrm{bp}$ ladder; lane 2: DNA of control; followed by lanes 3-7: DNA of AM-AuNP-treated HCT-15 cells exposed to 5, 10, 20, 25, and $50 \mu \mathrm{g} / \mathrm{mL}$ respectively of lane 8 is $1 \mathrm{~kb}$ ladder

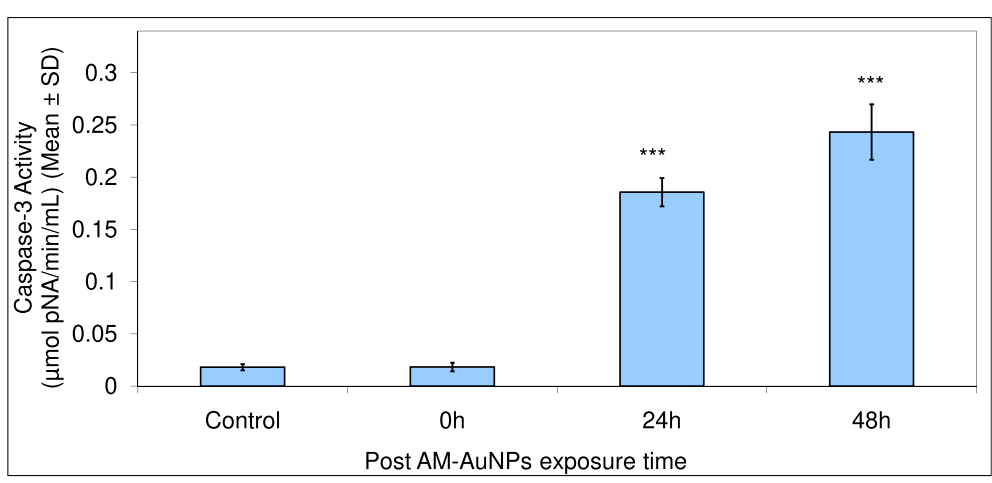

(a) Caspase-3 assay

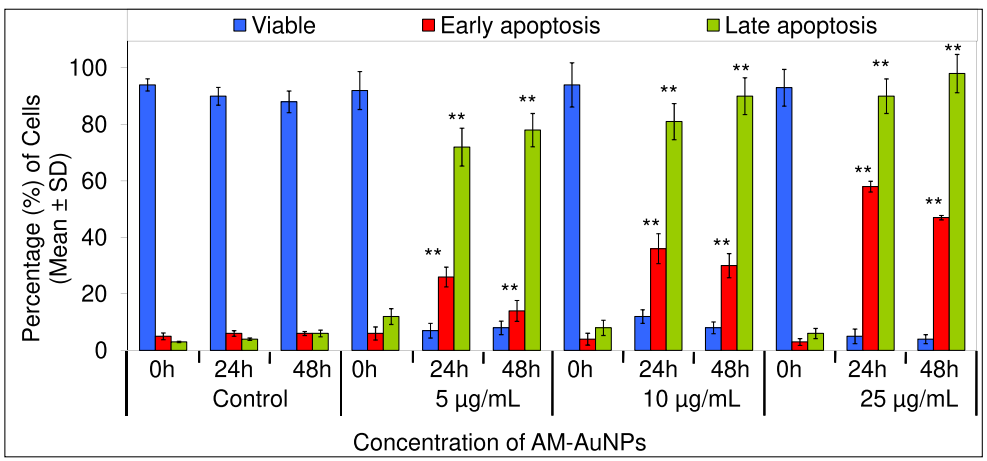

(b) Annexin-V apoptosis assay

Fig. 6 a Representative histogram showing caspase-3 activity in HCT-15 cells. Error bars indicate the standard deviation of three independent experiments $(n=3)$. Levels of significance in caspase-3 activity, $\mu \mathrm{molpNA} / \mathrm{min} / \mathrm{ml}$ between control and AM-AuNPs exposed cell samples assessed by Student's $t$ test are marked by ${ }^{* *} p<0.0001$, which was found to be increased significantly in protein samples obtained from $24 \mathrm{~h}$ and $48 \mathrm{~h}$ post exposure periods as compared to control cell samples. $\mathbf{b}$ Histogram showing analysis of Annexin V-FITC-PI staining of AM-AuNP-treated HCT-15 cells for 0,24 , and $48 \mathrm{~h}$. Data presented were expressed as mean \pm SD. Significant differences are indicated ${ }^{* *} p<0.001$ found to be increased significantly in cell samples obtained from 24 and $48 \mathrm{~h}$ post exposure to AM-AuNPs as compared to normal control cells 


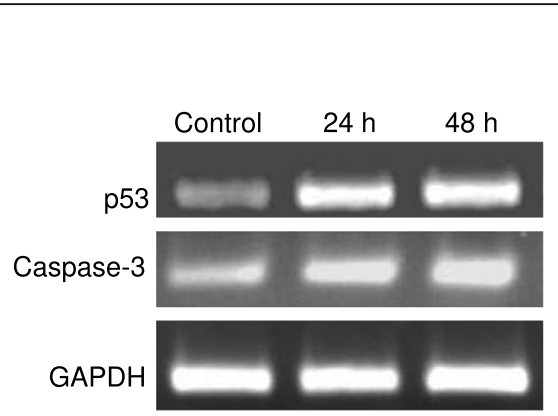

(a) Relative expression levels of p53 \& caspase- 3 mRNA in HCT-15 cells

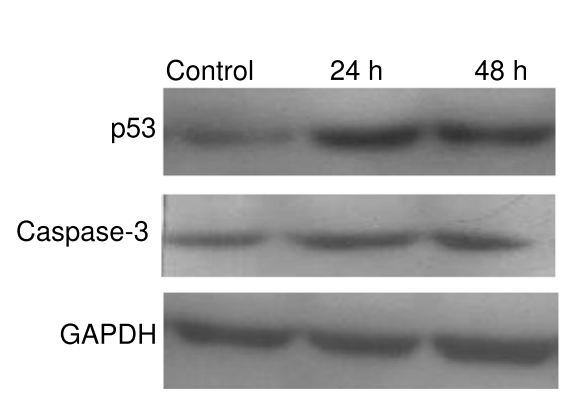

(c) Relative expression levels of p53 \& caspase- 3 protein in HCT-15 cells

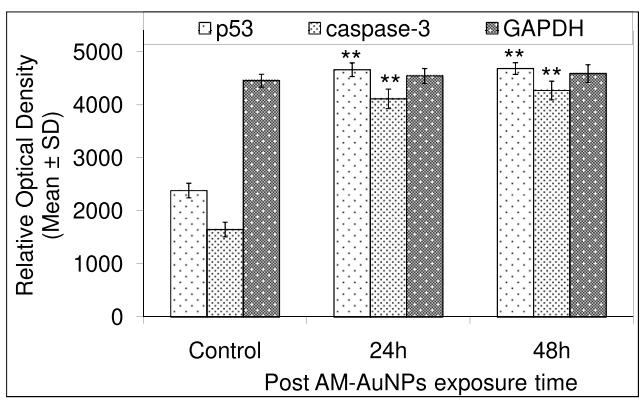

(b) Densitometric analysis of p53 \& caspase-3 mRNA expression in HCT-15 cells

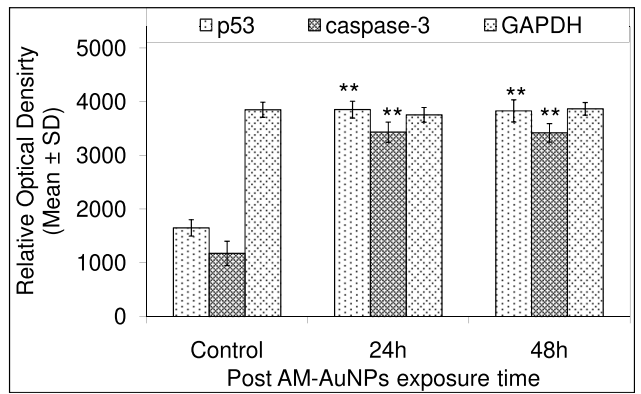

(d) Densitometric analysis of p53 \& caspase- 3 protein expression in HCT-15 cells

Fig. 7 a Representative semi-quantitative RT-PCR demonstrates the gene expression changes for p53, caspase-3, and GAPDH from HCT-15 cells exposed to $I C_{50}$ concentration of AM-AuNPs with different time points of exposure 24 and $48 \mathrm{~h}$. Lane 1 is control; lanes 2 and 3 are mRNA levels of AM-AuNPs exposed cell samples after $24 \mathrm{~h}$ and $48 \mathrm{~h}$ of exposure. $\mathbf{b}$ Histogram showing densitometry analysis of intrinsic apoptosis-related gene expressions of HCT-15 cells after exposure to AM-AuNPs for 24 and $48 \mathrm{~h}$. Error bars indicate standard deviation of mean for three independent experiments. GAPDH expression was used as loading control. c Representative immunoblot showing expression of apoptosis

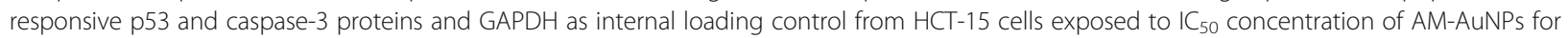
24 and $48 \mathrm{~h}$. d Histogram showing densitometry quantification of apoptotic protein expression. Significant differences assessed by Student's $t$ test are indicated in ${ }^{* *} p<0.001$, found to be increased significantly in samples obtained from $24 \mathrm{~h}$ and $48 \mathrm{~h}$ post exposure periods as compared to unexposed control. Error bars indicate standard deviation of mean for three independent experiments

cytotoxicity and genotoxicity effects of AuNPs synthesized using the $A$. mexicana plant extract. Several studies have reported the plant-mediated biosynthesis of gold nanoparticles, which demonstrated the involvement of phytoconstituents such as alkaloids, flavonoids, and polyphenols in the bioreduction of $\mathrm{Au}^{+}$ions to $\mathrm{Au}^{0}$ nanoparticles [24-28]. The antimicrobial and antiparasitic along with cytotoxicity potential have been reported already. Thus, we attempted the biogenic synthesis and exploration of the antiproliferative and genotoxic properties of AM-AuNPs by using colon carcinoma cell line. The biogenic AM-AuNPs exhibited dose-dependent cytotoxic effects with maximum inhibition of growth of HCT-15 cells at $50 \mu \mathrm{g} / \mathrm{mL}$. Several researchers have reported the cytotoxic effects of biosynthesized AuNPs on different cancer cell lines. The in vitro cytotoxicity of biogenic AuNPs synthesized using Marsilea quadrifolia exhibited an $\mathrm{IC}_{50}$ of $45.88 \mu \mathrm{g} / \mathrm{mL}$ toward the PA-1 cell line and $52.01 \mu \mathrm{g} / \mathrm{mL}$ against the A549 cell line [29]. Biologically synthesized gold nanoparticles from Enicostema axillare exhibited a strong cytotoxic effect against the MCF-7 cell line [30]. Munawer et al. also evaluated anticancer potential of AuNPs developed using the aqueous extract of Commiphora wightii and observed an $\mathrm{IC}_{50}$ of $66.11 \mu \mathrm{g} / \mathrm{mL}$ against the breast cancer cell line [31]. Several studies have described the in vitro cytotoxic effects of biogenic AuNPs on several cancer cell lines such as MCF 7, Caco-2, HePG2, and KMST-6 [32]. Similarly, other studies have observed that $100 \mu \mathrm{g} / \mathrm{mL}$ of biogenic AuNPs synthesized using Nothaphodytes foetida was required to inhibit 90\% growth of HeLa, MCF-7, and HCT-15 cells [33].

Biogenic nanoparticles exhibited cellular apoptosis through a decrease in cell proliferation and an increase in nuclear fragmentation. Our results are concurrent with those of our previous studies when we considered DNA fragmentation-induced apoptosis in HCT-15 cells exposed to biogenic AM-AuNPs. The nuclear DNA fragmentation revealed extensive double-stranded breaks in the DNA of HCT-15 cells when exposed to 
20-50 $\mu \mathrm{g} / \mathrm{mL}$ AM-AuNPs, whereas the control cells exhibited intact DNA without prominent DNA laddering visible on the agarose gel. Additionally, the apoptotic effects of nanoparticles were confirmed by caspase- 3 activation. To examine the status of caspase- 3 , the caspase- 3 activity of HCT-15 cells was observed in response to AM-AuNPs. Its expression increased significantly after 24 and $48 \mathrm{~h}$ of exposure. Further, we attempted to understand the mechanism of apoptosis through the Annexin- $\mathrm{V}$ assay, where the treatment of cells with an increasing concentration of AM-AuNPs at different incubation periods induced apoptosis in the HCT-15 cell line. This exhibited a shift in the cell population from viable to early apoptosis, and thereafter to the late apoptosis stage. Similar results were reported in gastric cancer and oral squamous cell carcinoma cell lines [34, 35], which demonstrated the status of apoptosis in response to nanoparticles. Inhibition of cell proliferation and induction of apoptosis are biological processes for the regulation of cell survival or death in response to physiological stress conditions. Thus, when HCT-15 cells were treated with an $\mathrm{IC}_{50}$ of AM-AuNPs up to $48 \mathrm{~h}$, a significantly increased expression of $\mathrm{p} 53$ and caspase- 3 at the mRNA and protein level was observed in the AMAuNP-treated HCT-15 cells in a time-dependent manner, which confirms the induction of apoptosis by AM-AuNPs. Biogenic nanoparticles induced programmed cell death in cancer cells through activation of apoptotic genes [36-39]. Additionally, caspase-3 activity in the AM-AuNP-treated HCT-15 cells was examined to address the potential role of caspase- 3 in the apoptotic pathway. The AM-AuNPs increased levels of caspase- 3 in the HCT-15 cell line. Thus, the intrinsic apoptotic pathway in HCT-15 cells is mediated through the involvement of p53 and activation of caspase-3 in response to biogenic AM-AuNP exposure.

\section{Conclusion}

The present study addressed the mechanism underlying the cytotoxic and genotoxic effects of biogenic gold nanoparticles synthesized using the aqueous extract of A. mexicana. The biosynthesized gold nanoparticles were confirmed through UV-visible spectroscopy, TEM, FTIR, and XRD analyses. The biogenic AM-AuNPs exhibited strong antiproliferative and apoptotic potential against the colon cancer cell line. Our investigation evidently confirmed the intrinsic apoptotic pathway as a core mechanism involved in the cell death of HCT-15 cells exposed to biogenic AM-AuNPs, which was confirmed through semi-quantitative RT-PCR and immunoblotting analysis.

\section{Abbreviations}

TEM: Transmission electron microscopy; XRD: X-ray diffraction; FTIR: Fourier transition infrared spectroscopy; MTT: 3-(4, 5-dimethylthiazol-2-yl)-2,5-diphenyltetrazolium bromide; IC50: 50\% inhibitory concentration; P53: Tumor suppressor protein; AM-AuNPs: Argemone mexicana gold nanoparticles; RTPCR: Reverse transcriptase-polymerase chain reaction

\section{Acknowledgements \\ The authors gratefully acknowledge all the facilities and financial support provided by the Krishna Institute of Medical Sciences "Deemed to be University" Karad, India, for experimental work. Authors are thankful to Mr. Santosh Jadhav for technical support.}

\section{Authors' contributions}

KDD, SRP: design of research theme; PPD, MNP, DDH, NJJ, VND, and ALM: experimental work. PPD, MNP, DDH: manuscript writing; KDD, PPD: analysis and interpretation of results. All authors read and approved the manuscript.

Funding

Intramural funding

Availability of data and materials

All data generated and analyzed in this study are included in this manuscript.

Ethics approval and consent to participate

Not applicable

\section{Consent for publication}

Not applicable

\section{Competing interests}

None declared

Received: 22 October 2020 Accepted: 29 December 2020

Published online: 14 January 2021

\section{References}

1. Daraee H, Eatemadi A, Abbasi E, Aval SF, Kouhi M, Akbarzadeh A (2016) Application of gold nanoparticles in biomedical and drug delivery. Artif Cell Nanomed B 44(1):410-422

2. Elahi N, Kamali M, Baghershad MH (2018) Recent biomedical applications of gold nanoparticles: a review. Talanta 184:537-556

3. Bray F, Ferlay J, Soerjomataram I, Siegel RL, Torre LA, Jemal A (2018) Global cancer statistics 2018: GLOBOCAN estimates of incidence and mortality worldwide for 36 cancers in 185 countries. CA: A Cancer J Clin 68(6):394424

4. Bobo D, Robinson KJ, Islam J, Thurecht KJ, Corrie SR (2016) Nanoparticlebased medicines: a review of FDA-approved materials and clinical trials to date. Pharm Res 33:2373-2387

5. Patra JK, Das G, Fraceto LF, Compas EVR, Rodriguez-Torres MP, Acosta-Torres LS, Diaz-Torres LA, Grillo R, Swaly MK, Sharma S, Habetmariam S, Shin HS (2018) Nano based drug delivery systems: recent developments and future prospects. J Nanobiotechnology 16:71. https://doi.org/10.1186/s12951-0180392-8

6. Kumar R, Dalvi SV, Siril PF (2020) Nanoparticle-based drugs and formulations: current status and emerging applications. ACS Appl Nano Mater 3(6):4944-4961

7. Yao Y, Zhou Y, Liu L, Xu Y, Chen O, Wang Y, Wu S, Deng Y, Zhang J, Shao A (2020) Nanoparticle-based drug delivery in cancer therapy and its role in overcoming drug resistance. Front Mol Biosci 7:193. https://doi.org/10.3389/ fmolb.2020.00193

8. Singh P, Pandit S, Mokkapati VRSS, Garg A, Ravikumar V, Mijakovic I (2018) Gold nanoparticles in diagnostics and therapeutics for human cancer. Int J Mol Sci 19:1979. https://doi.org/10.3390/ijms19071979

9. Goel A, Bhatia AK (2019) Phytosynthesized nanoparticles for effective cancer treatment: a review. Nanosci Nanotech Asia 4(9):437-443

10. Mahato K, Nagpal S, Shah MA, Srivastava A, Maurya PK, Roy S, Jaiswal A, Singh R, Chandra P (2019) Gold nanoparticle surface engineering strategies and their applications in biomedicine and diagnostics. 3 Biotech 9:57. https://doi.org/10.1007/s13205-019-1577-z 
11. Irshad A, Zahid M, Husnain T, Rao AQ, Sarwar N, Hussain I (2020) A proactive model on innovative biomedical applications of gold nanoparticles. Appl Nanosci 10:2453-2465

12. Zahin N, Anwar R, Tewari D, Kabir T, Sajid AMathew B, Uddin S, Aleya L, Abdel-Daim MM (2020) Nanoparticles and its biomedical applications in health and diseases: special focus on drug delivery. Enviorn Sci Pollut Res 27:19151-19168

13. Singh AK, Tiwari $R$, Singh $V K$, Singh $P$, Khadim $A R$, Singh $U$, Shrivastava $V$, Hasan SH, Asthana RK (2019) Green synthesis of gold nanoparticles from Dunaliella salina, its characterization and in vitro anticancer activity on breast cancer cell line. J Drug Deliv Sci Technol 51:164-176

14. Divakaran D, Lakkakula JR, Thakur M, Kumawat MK, Srivastava R (2019) Dragon fruit extract capped gold nanoparticles: synthesis and their differential cytotoxicity effect on breast cancer cells. Mater Lett 236:498-502

15. Anand K, Gengan RM, Phulukdaree A, Chuturgoon A (2015) Agroforestry waste Moringa oleifera petals mediated green synthesis of gold nanoparticles and their anti-cancer and catalytic activity. J Ind Eng Chem 21:1105-1111

16. Abel EE, Poonga PRJ, Panicker SG (2016) Characterization and in vitro studies on anticancer, antioxidant activity against colon cancer cell line of gold nanoparticles capped with Cassia tora SM leaf extract. Appl Nanosci 6(1):121-129

17. Wu T, Duan X, Hu C, Wu C, Chen X, Huang J, Liu J, Cui S (2019) Synthesis and characterization of gold nanoparticles from Abies spectabilis extract and its anticancer activity on bladder cancer T24 cells. Artificial Cells, Nanomed Biotechnol 47(1):512-523

18. Pan Y, Leifert A, Ruau D, Neuss S, Bornemann J, Schmid G, Barandu W, Simon U, Jahnsen-Dechent W (2009) Gold nanoparticles of diameter $1.4 \mathrm{~nm}$ trigger necrosis by oxidative stress and mitochondrial damage. Small 9(5): 2067-2076

19. Kang B, Mackey MA, El-Sayed MA (2010) Nuclear targeting of gold nanoparticles in cancer cells induces DNA damage, causing cytokinesis arrest and apoptosis. J Am Chem Soc 132:1517-1519

20. Jain S, Hirst DG, Sulivan JM (2012) Gold nanoparticles as novel agents for cancer therapy. Br J Radiol 85(1010):101-113

21. Singh S, Verma M, Malhotra M, Prakash S, Singh TD (2016) Cytotoxicity of alkaloids isolated from Argemone mexicana on SW480 human colon cancer cell line. Pharm Biol 54(4):740-745

22. Datkhile KD, Patil SR, Durgawale PP, Patil MN, Jagdale NJ, Deshmukh VN (2020a) Studies on phytoconstituents, in vitro antioxidant, antibacterial and cytotoxicity potential of Argemone mexicana Linn. (family: Papaveraceae). J Nat Sci Biol Med 11:198-205

23. Datkhile KD, Patil SR, Durgawale PP, Patil MN, Jagdale NJ, Deshmukh VN, More AL (2020b) Biogenic silver nanoparticles synthesized using Mexican poppy plant inhibits cell growth in cancer cells through activation of intrinsic apoptosis pathway. Nano Biomed Eng 12(3):241-252

24. Santhoshkumar J, Rajeshkumar S, Venkat Kumar S (2017) Phyto-assisted synthesis, characterization and applications of gold nanoparticles-a review. Biochem Biophys Rep 11:46-57

25. Teimuri-Mofrad R, Hadi R, Tahmasebi B, Farhoudian S, Mehravar M, Nasiri R (2017) Green synthesis of gold nanoparticles using plant extract: minireview. Nano Res 2(1):8-19

26. Vijayaraghavana K, Ashokkumar T (2017) Plant-mediated biosynthesis of metallic nanoparticles: a review of literature, factors affecting synthesis, characterization techniques and applications. J Environ Chem Eng 5(5): 4866-4883

27. Khandel P, Yadaw RK, Soni DK, Kanwar L, Shahi SK (2018) Biogenesis of metal nanoparticles and their pharmacological applications: present status and application prospects. J Nanostructure Chem 8:217-254

28. Singh J, Dutta T, Kim K, Rawat M, Samddar P, Kumar P (2018) Green synthesis of metals and their oxide nanoparticles: applications for environmental remediation. J Nanobiotechnology 16:84. https://doi.org/10. 1186/s12951-018-0408-4

29. Balashanmugam P, Mosa Christas K, Kowsalya E (2018) In vitro cytotoxicity and antioxidant evaluation of biogenic synthesized gold nanoparticles from Marselia quadrifolia on lung and ovarian cancer cells. Int J App Pharm 10(5): $153-158$

30. Arvindganth R, Kathiravan G (2019) Biogenic synthesis of gold nanoparticle from Enicostema axillare and their in vitro cytotoxicity study against MCF-7 cell line. Bionanoscience 9:839-847
31. Munawer U, Ningaraju S, Basavegoda VR, Chakkere AM, Shanmuganthan R, Kathirvel B (2020) Biogenic synthesis of gold nanoparticles using Commiphora wightii and their cytotoxic effects on breast cancer cell line (MCF-7). Process Biochem 92:269-276

32. Majoumouo MS, Sharma JR, Sibuyi NRS, Tincho MB, Boyom FF, Meyer M (2020) Synthesis of biogenic gold nanoparticles from Terminalia mantaly extracts and the evaluation of their in vitro cytotoxic effects in cancer cells. Molecules 25:4469

33. Datkhile KD, Durgawale PP, Patil MN, Jagdale NJ, Deshmukh VN (2020c) Biosynthesis characterization and evaluation of biological properties of biogenic gold nanoparticles synthesized using Nothapodytes foetida leaf extract. Nanosci Nanotech Asia. https://doi.org/10.2174/ 22106812106662002002

34. Mousavi B, Tafvizi F, Zaker SB (2018) Green synthesis of silver nanoparticles using Artemisia turcomanica leaf extract and the study of anti-cancer effect and apoptosis induction on gastric cancer cell line (AGS). Artificial Cells Nanomed Biotechnol 46(1):499-510

35. Yakop F, Abd Ghafar SA, Yong YK, Yazan LS, Hanafiah RM, Lim V, Eshak Z (2018) Silver nanoparticles Clinacanthus Nutans leaves extract induced apoptosis towards oral squamous cell carcinoma cell lines. Artificial Cells Nanomed Biotechnol 46(2):131-139

36. Selim ME, Hendi AA (2012) Gold nanoparticles induce apoptosis in MCF-7 human breast cancer cells. Asian Pac J Cancer Prev 13(4):1617-1620

37. Ma DD, Yang WX (2016) Engineered nanoparticles induce cell apoptosis: potential for cancer therapy. Oncotarget 7(26):40882-40903

38. Nagarajan K, Deyu L, Soundarpandian K (2019) Induction of intrinsic apoptotic signaling pathway in A549 lung cancer cells using silver nanoparticles from Gossypium hirsutum and evaluation of in vivo toxicity. Biotechnol Rep 23:e00339

39. Kumari R, Saini AK, Kumar A, Saini RV (2020) Apoptosis induction in lung and prostate cancer cells through silver nanoparticles synthesized from Pinus roxburghii bioactive fraction. J Biol Inorg Chem 25:23-37

\section{Publisher's Note}

Springer Nature remains neutral with regard to jurisdictional claims in published maps and institutional affiliations.

\section{Submit your manuscript to a SpringerOpen ${ }^{\circ}$ journal and benefit from:}

- Convenient online submission

Rigorous peer review

- Open access: articles freely available online

High visibility within the field

- Retaining the copyright to your article

Submit your next manuscript at $>$ springeropen.com 